\title{
The Genus Jobertus Distant, 1884 (Hemiptera: Miridae:Orthotylinae) ${ }^{1}$
}

\author{
J. Maldonado Capriles ${ }^{2}$ \\ ABSTRACT
}

The genus Jobertus is defined; two new species, J. nigricephalus and $J$. nigrithorax from Panamá are described. A key to the six species in the genus is given.

\section{INTRODUCTION}

The genus Jobertus includes delicate, small, mostly pale greenish insects that can be separated from other genera in Orthotylini as follows: first antennal segment cylindrical, thicker than the others, about as long or longer than width of vertex, slightly longer than length of head, and mostly bare; vertex convex, with a small but well defined basal carina; eye bluntly margined behind (fig. 20); without a neck; beak reaching to or beyond posterior coxae; pronotum trapezoidal, without lateral suture or carina, usually not strongly constricted, not projected over scutellum, posterior margin nearly straight above mesoscutum or shallowly concave, and calli poorly defined and without punctures behind; scutellum slightly swollen, smooth; forewing translucent, with cuneus 2 to 3 times longer than wide, membrane with two cells, and membrane cells are of same texture as corium; pilosity long, fine, and relatively scarce.

The characters listed above are given as they appear in Carvalho's key to the Orthotylini genera of the world (4). A character that can be used for rapid identification of the genus is the shape of the head behind the eyes (fig. 20). The head of Itacoris, a very close genus, is illustrated (fig. 21) for comparison.

This neotropical genus now includes six species that can be identified by means of the key given at the end. The types of the new species are deposited in the collection of the National Museum of Natural History (NMNH), Washington, D.C., the collection of J.C.M. Carvalho (Carv), Río de Janeiro, Brazil, and the author's (JMC). In the descriptions that follow 20 micrometer units are equivalent to $1.0 \mathrm{~mm}$.

\section{DESCRIPTIONS}

\section{Jobertus nigrithorax NEW SPECIES}

Male. Pale greenish body and appendages. Black as follows: head above and in front to base of jugum, pronotum above except at humeral angles,

${ }^{\mathrm{I}}$ Manuscript submitted to Editorial Board August 21, 1979.

${ }^{2}$ Department of Anatomy, School of Medicine, Catholic University, Ponce, P.R., and Department of Crop Protection, Agriculture Experiment Station, University of Puerto Rico, Mayagüez, PR 00708. 

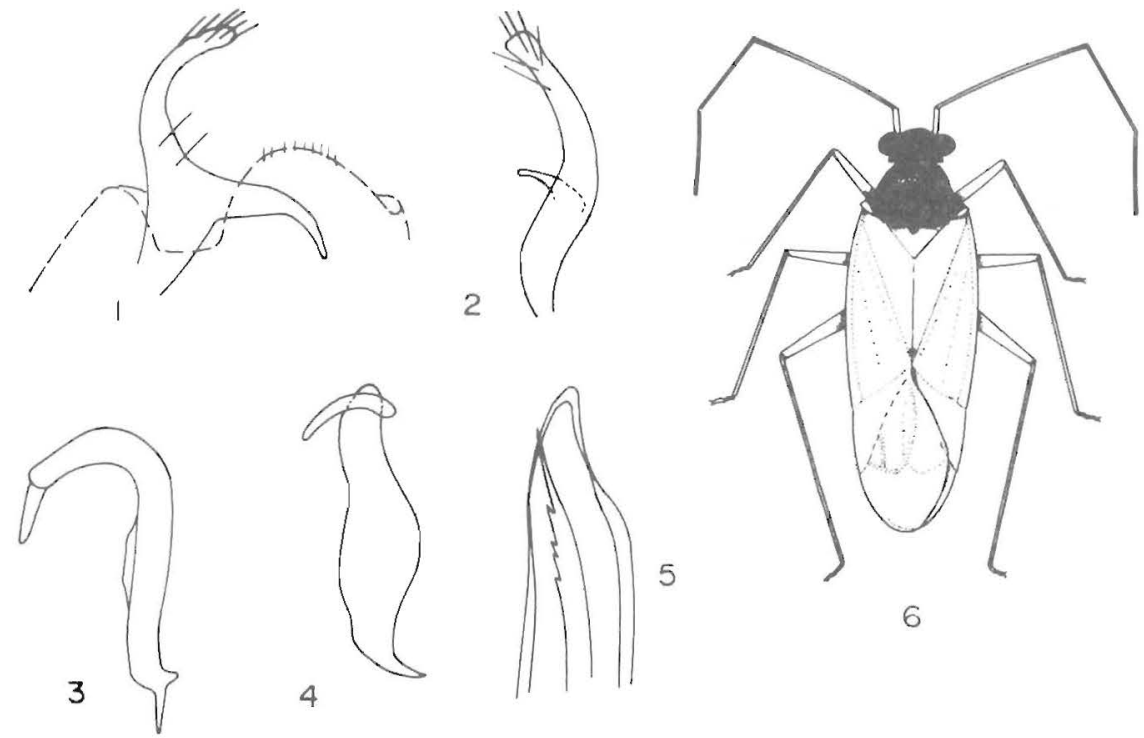

6
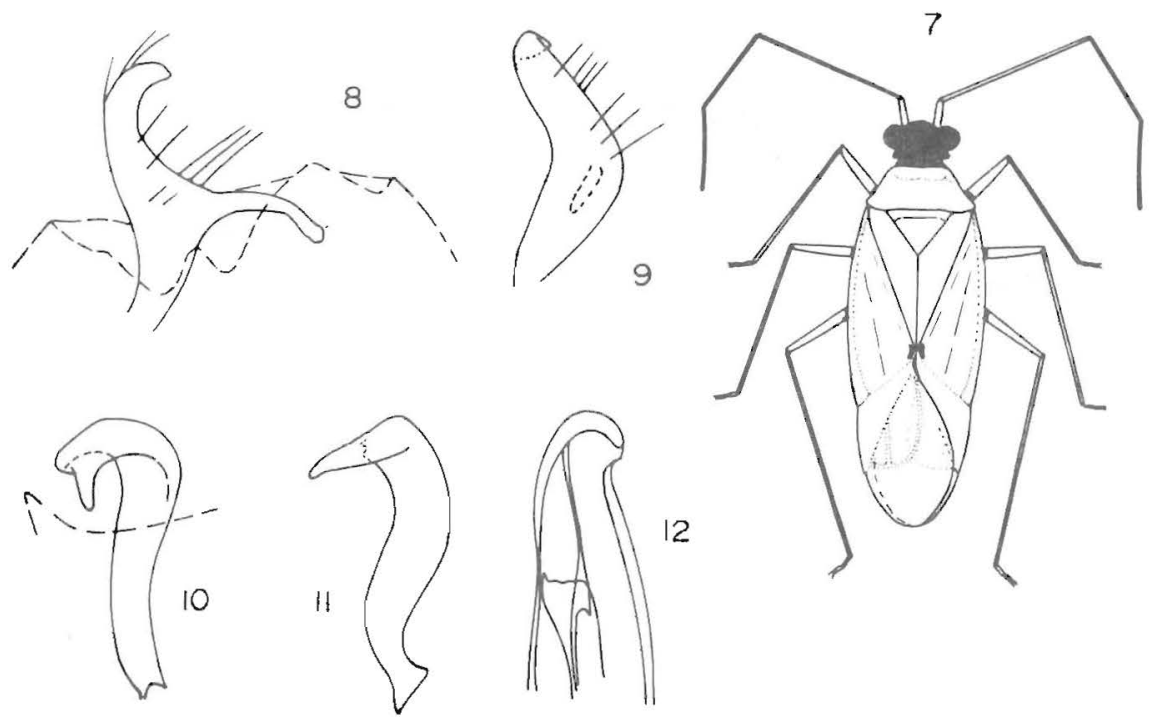

PLATE I. Jobertus nigrithorax n. sp. male 1. right clasper in situ, ventral. 2. right clasper, lateral. 3. left clasper, ventral. 4. left clasper, lateral. 5. apex of aedeagus and tip of vesica. 6. habitus. Jobertus nigricephalus n. sp., male. 7. habitus. 8. right clasper, ventral. 9. right clasper, lateral. 10. left clasper, ventral. 11. left clasper, lateral. 12. apex of aedeagus and tip of vesica. 
pronotum laterally anteriorly from about the level of the inferior margin of the eye and posteriorly to below the humeral angle, mesoscutum, and base of scutellum.

Head: Width across eyes 9.5; vertex with fine posterior carina, width narrowest part 4; length 4. Antennal segments: I, 4.5; II, 21; III, 9; IV, missing in all specimens. Pronotum: length 8, width at humeral angles 15, posterior margin straight above mesoscutum; mesoscutum 1, scutellum
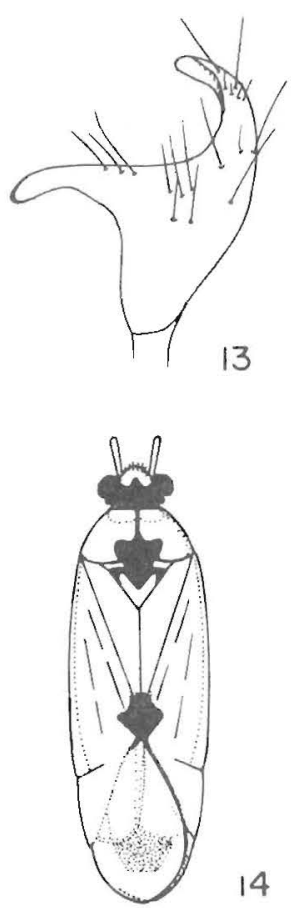

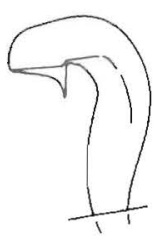

15

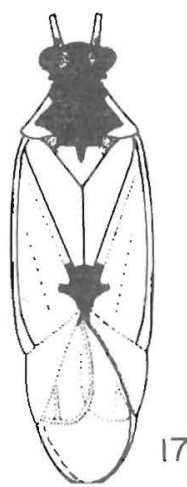

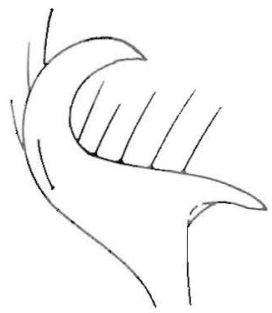

16
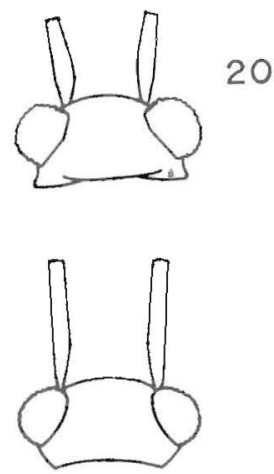

21

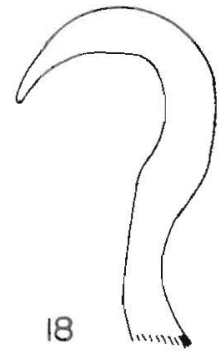

18

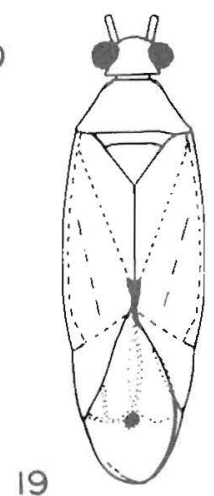

Plate II. Jobertus esavianus. 13. right clasper, dorsal. 14. habitus. Jobertus chryselectrus. 15. left clasper, dorsal. 16. right clasper, ventral. 17. habitus. Jobertus gracilentus. 18. left clasper, ventral. 19. habitus. Jobertus sp. 20. head, dorsal. Itacoris sp. 21. head, dorsal.

as long as wide (6:6). Beak reaching to first abdominal segment. Cuneus slightly over $3 \times$ longer than wide (10:3). Habitus as in figure 6; genitalia as in figures 1 to 5 . Length $2.5-2.6 \mathrm{~mm}$, width $0.8-0.85 \mathrm{~mm}$.

Female. Coloration, shape, and pilosity as in male. Head: width across eyes 9.2 ; width of vertex 4 , length 4 . Antennal segments: I, 5; II, 19; III, 5; IV, missing. Pronotum: width 14.5, length 7; mesoscutum 1; scutellum as wide as long (6:6). Beak reaching to first abdominal segment. Cuneus nearly $3 \times$ longer than wide (10:3.5). Length $2.6-2.65 \mathrm{~mm}$, width $0.8-0.85$.

Holotype, male, outskirts of Porto Bello, PANAMA, Jan 1971, JMC 
collector, in NMNH, Cat No. 76192. Allotype, female, same data, in NMNH. Paratypes 8, of both sexes, same data, one in NMNH, two in Carv, and 5 in JMC. The relationships of these species are discussed below.

\section{Jobertus nigricephalus NEW SPECIES}

Male. Pale greenish body and appendages; black as follows: eyes, vertex, frons down to base of jugum, collar, and spot before anal ridge.

Head: Width across eyes 11, width of vertex across narrowest part 3, length 4. Antennal segments: I, 5; II, 22; III and IV missing. Beak reaching to apex of metacoxa. Pronotum: width at humeral angles 15.5, length 7. Mesoscutum 1, scutellum slightly wider than long (6:5). Cuneus $3 \times$ longer than wide (9:3). Pilosity as described for genus. Length 2.5 , width $0.9 \mathrm{~mm}$. Habitus as in figure 7, genitalia as in figures 8 to 12 . Length $2.5 \mathrm{~mm}$., width 0.9 .

Female. Coloration, shape, and pilosity as in male. Head: width across eyes 10.2, width of vertex at narrowest part 3, length 4 . Antennal segments: I, 5; II, 18; III and IV missing. Pronotum: width across humeral angles 16, length 7 , mesoscutum 1, scutellum slightly wider than long (7:5), Cuneus $3 \times$ longer than wide (9:3). Length $2.7 \mathrm{~mm}$. width $1.0 \mathrm{~mm}$.

Holotype, male, outskirts of Porto Bello, PANAMA, Jan 1971, JMC collector, NMNH Cat. No. 76191. Allotype, female, same data, in NMNH. Paratype one male in JMC. Although the coloration of J. nigrithorax puts it closer to J. chryselectrus the genitalia of J. nigricephalus are closer to that of the latter. Both new species were collected from the underside of leaves of a tree belonging to the family Eretiaceae, perhaps a Cordia.

Jobertus esavianus Carvalho 1944 (1)

Described from Brazil. Figure 14 illustrates the habitus and figure 13 the right clasper, both redrawn from Carvalho.

Jobertus chryselectrus Distant 1893 (7)

Described from Mexico and Guatemala. Known from Cuba, Santo Domingo (in JMC), and Puerto Rico. Figure 17 illustrates the habitus, figure 16 the right clasper, and 15 the left clasper.

Jobertus gracilentus Carvalho and Becker 1959 (6)

Described from Puerto Rico. Overlooked in my paper The Miridae of Puerto Rico (8). Later also collected by me at El Yunque, Puerto Rico. Care must be taken not to confuse it with Itacoris nigrioculis Carvalho because these two have almost identical shape and coloration, i.e., uniformly pale greenish, blackish anal ridge, and a dark spot touching the 
large cell of the membrane (fig. 19). They can be separated by the shape of the head (figs. 20,21) different pilosity, and the genitalia. The left clasper (fig. 18, after Carvalho) is of the same type as that of esavianus.

\section{Jobertus sanguiniceps (Stal)}

Described from Mato Grosso, Brazil. Originally described in Cyllecoris, then moved to Dicyphus (3), Cyrtopeltis, and finally to Jobertus by Carvalho (4). For complete bibliography, see Carvalho (5). It is the only species ornamented with red.

\section{KEY TO THE SPECIES OF JOBERTUS}

1. First antennal segment pale yellowish ${ }^{3}$ or greenish $\ldots \ldots \ldots \ldots .2$ First antennal segment totally black or at least with a basal black

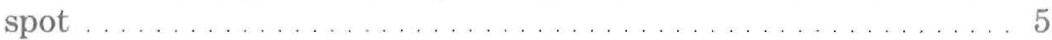

2. Head brownish with black basal margin; pronotum with a black inverted-T on posterior lobe (fig. 14) ....... J. esavianus Carvalho Head totally black or pale yellowish; pronotum differently colored 3

3. Head and pronotum yellowish ${ }^{3}$ or greenish (fig. 19)

J. gracilentus Carvalho \& Becker

Head black

4. Head, pronotum, and mesoscutum black (fig. 6) .J. nigrithorax n. sp. Head black, pronotum except collar, and mesoscutum greenish (fig. 1) J. nigricephalus $\mathrm{n}$. $\mathrm{sp}$.

5. First antennal segment black; head and pronotum ornamented with red J. sanguiniceps (Stal) First antennal segment greenish, above with black spot near base and pronotum mostly black (fig. 17) J. chryselectrus Distant

\section{RESUMEN}

Se define el género Jobertus, se describen dos especies nuevas colectadas por el autor en Panamá y se ofrece una clave para identificar las seis especies del género.

\section{LITERATURE CITED}

1. Carvalho, J. C. M., 1944. Mirídeos neotropicais: Sobre os gêneros Jobertus Dist., Parachius Dist. e Pliniella Berg. (Hemiptera). Rev. Ent. 15 (1-2): 162-71.

2. - 1947. Mirideos Neotropicais, XXVII: Gêneros Porpomiris Berg, Lampethusa Distant, Cyrtopeltis Fieber e Dicyphus Fieber (Hemiptera). Bol. Mus. Nac. 77: 1-23, 62 fig.

3. - 1952. Neotropical Miridae, LI: on the present generic assignment of the species in "Bidrag till Rio Janeiro-traktens Hemipter-Fauna" (Hemiptera) Rev. Brasil. Biol. 12 (2): $215-7$.

4. - 1955. Chaves para os gêneros de Mirídeos do mundo (Hemiptera), Bol. Mus. Paraense Emilio Goeldi 11 (2): 1-151.

${ }^{3}$ Probably greenish in life. 
5. — , 1958. Catálogo dos mirídeos do mundo. Parte III. Arq. Mus. Nac. 47: 1-161.

6. - and Becker, J., 1959. Neotropical Miridae, LXXXV: new species of Orthotylinae in the collection of the United States National Museum (Hemiptera, Heteroptera). An. Acad. Brasil. Cien. 31 (1): 113-7.

7. Distant, W. L., 1884-1893. Biología Centrali Americana, Insecta, Rhynchota, Hemiptera-Heteroptera, Vol. 1: 1-302. Supplement-pp. 304-462.

8. Maldonado Capriles, J., 1969. The Miridae of Puerto Rico (Insecta, Hemiptera), Agri. Exp. Stn. Univ. P.R., Tech Paper 45: 1-33. 